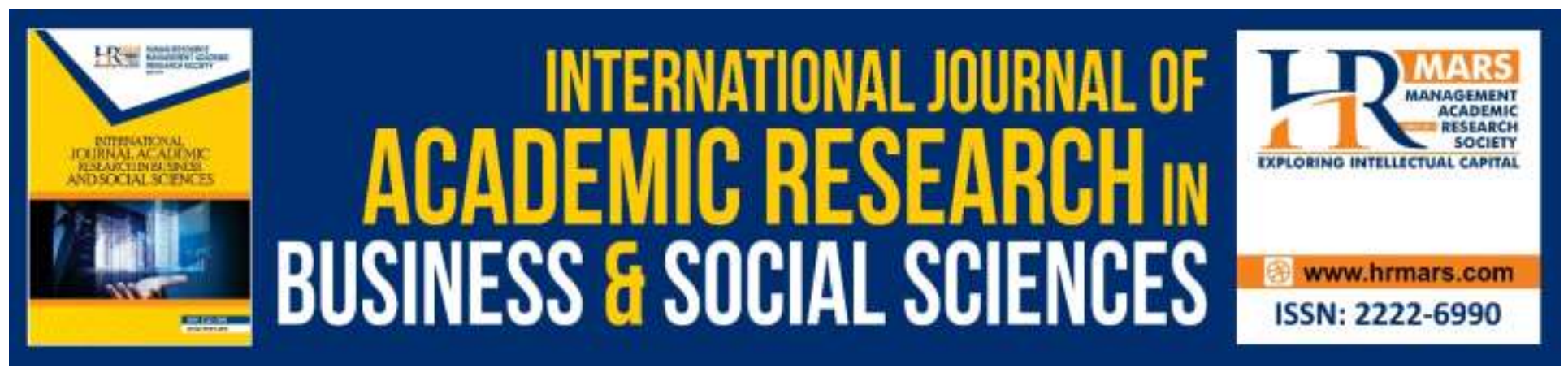

\title{
Exploring Women's Representation at the Top of Leading Social Enterprises
}

Carla Del Gesso and Luca Romagnoli

To Link this Article: http://dx.doi.org/10.6007/IJARBSS/v10-i3/7062

DOI:10.6007/IJARBSS/v10-i3/7062

Received: 04 February 2020, Revised: 20 February 2020, Accepted: 13 March 2020

Published Online: 24 March 2020

In-Text Citation: (Del Gesso \& Romagnoli, 2020)

To Cite this Article: Del Gesso, C., \& Romagnoli, L. (2020). Exploring Women's Representation at the Top of Leading Social Enterprises. International Journal of Academic Research in Business and Social Sciences, 10(3), 453-469.

Copyright: (C) 2020 The Author(s)

Published by Human Resource Management Academic Research Society (www.hrmars.com)

This article is published under the Creative Commons Attribution (CC BY 4.0) license. Anyone may reproduce, distribute, translate and create derivative works of this article (for both commercial and non-commercial purposes), subject to full attribution to the original publication and authors. The full terms of this license may be seen

at: http://creativecommons.org/licences/by/4.0/legalcode

Vol. 10, No. 3, 2020, Pg. 453 - 469

http://hrmars.com/index.php/pages/detail/IJARBSS

JOURNAL HOMEPAGE

Full Terms \& Conditions of access and use can be found at http://hrmars.com/index.php/pages/detail/publication-ethics 


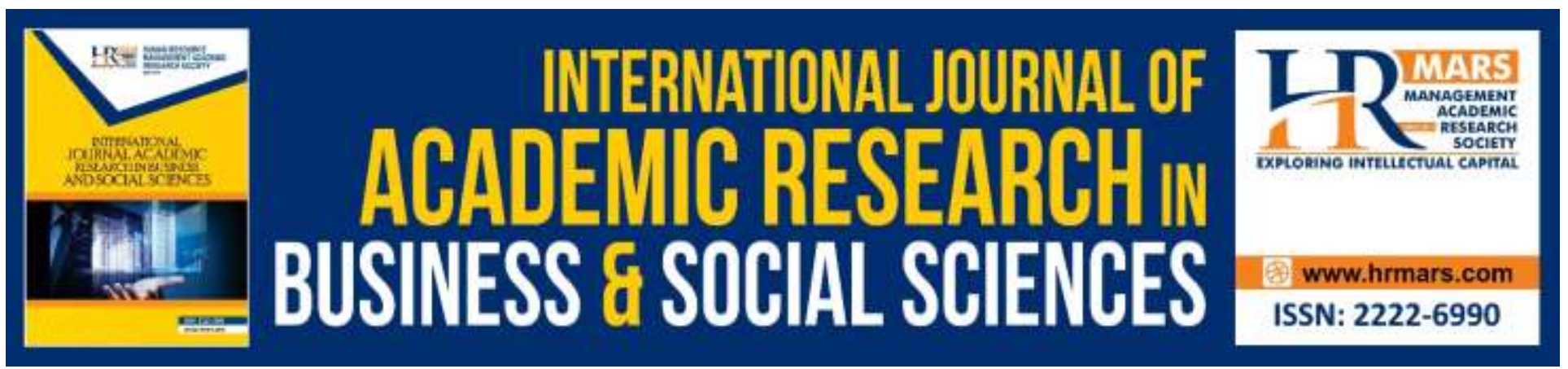

\title{
Exploring Women's Representation at the Top of Leading Social Enterprises
}

\author{
Carla Del Gesso and Luca Romagnoli \\ Department of Economics, University of Molise, Campobasso, Italy
}

\begin{abstract}
Social enterprises (SEs) have great potential for the promotion of gender-balanced corporate governance and decision-making. The limited research on the subject has shown that women are still under-represented in SE leadership positions. However, no generalizable studies exploring women's representation in corporate governance and managerial roles within the SE environment are available. In an attempt to gain more knowledge about the potential for SEs to achieve genderbalanced corporate leadership, this study explores women's representation at the top of a sample of 60 world leading SEs operating in different continents in a variety of macro-sectors of activity. A quantitative analysis of the data from the SEs sampled was performed by combining descriptive and inferential statistics. The findings offer an overall picture of women's representation at the top of SEs. They show how representation is spread differently in the various sectors of activity and in different geographical areas. Despite SEs not having yet reached a gender-balanced corporate leadership on a global scale, the great potential for SEs to encourage women's involvement in decision-making was confirmed. Research implications are identified, and greater efforts are recommended so that this potential can be substantiated in achieving gender-balanced management and governance systems.
\end{abstract}

Keywords: Gendered Leadership, Corporate Governance, Social Enterprises, Gender Balance, Women's Empowerment.

\section{Introduction}

The representation of women in corporate governance and managerial roles, although increasing, still appears to be a social issue. Indeed, women are still under-represented as leaders of organizations, both in the profit and non-profit sectors, and therefore, the gender gap remains a social challenge for advancing women's empowerment and gender equality (Hoyt, 2010; Teasdale et al., 2011; Claus et al., 2013; Glass \& Cook, 2016).

Social enterprises (SEs), however, have great potential for reducing gender gaps and promoting women's involvement in decision-making roles (Lyon \& Humbert, 2012; Nicolás \& Rubio, 2016; Nair, 2019). This is because SEs play an increasingly important role in tackling global and 
pressing socio-economic challenges such as the reduction of gender inequality and women's poverty, by virtue of their distinctive business features that can act as a powerful engine of sustainable societal development and cultural change (Fotheringham \& Saunders, 2014; Doherty, 2018; Del Gesso, 2020). In accordance with this idea, some scholars have highlighted how the gender gap is less prominent in SEs compared to commercial enterprises (Nicolás \& Rubio, 2016; Nair, 2019). However, the potential for SEs to stimulate more egalitarian gender development paths, particularly in terms of the balanced participation of men and women in corporate governance and decision-making, has not yet been sufficiently explored. Research on this subject has shown that women tend to be underrepresented in leadership positions in SEs and that gender imbalance appears to persist, but this has only been demonstrated with reference to a sample of SEs in the UK (Teasdale et al., 2011; Lyon \& Humbert, 2012). Hence, little attention has been paid to women's participation in the governance of SEs and there are no generalizable studies that have examined gender diversity at their top.

Due to this lack of research and the belief that there is a need to extend the debate surrounding this subject, the present study aims to explore women's representation at the top of world leading SEs. It attempts to gain more knowledge about the potential for SEs to achieve gender balance in their leadership and corporate boards, by analyzing a sample of sixty successful SEs operating in different locations across the world in a variety of macro-sectors of activity. Data were hand-collected from the institutional websites of the SEs sampled and were processed using quantitative measures.

The findings of the empirical research reported here give an in-depth look at the presence of women in the corporate leadership of leading SEs in the world. This is important to better understand the extend of women's involvement at the top of contemporary SEs. Such an improved understanding may be useful in order to help these organizations to enhance the key role they have in addressing global socio-economic challenges. It could also inform policies aimed at promoting sustainable development and change in society, such as those relating to gender equality. The research findings may also contribute to the advancement of the theoretical debate on gender issues in the SE sector.

The remainder of this paper is organized as follows: the following section presents a review of the related existing literature and the hypotheses behind the study. The third section describes the study sample, data collection and analysis methods used. The results of the statistical analyses on the basis of which the study hypotheses are tested are presented in the subsequent section. The final section discusses the study results in connection with the findings of previous studies by highlighting the research implications and recommending greater efforts for a better gender balance in SE governance and decision-making.

\section{Literature Review and Hypotheses Building}

The participation of women in leadership roles, such as board members and top managers, has been shown to favor the social and sustainability orientation of non-profit organizations (Périlleux \& Szafarz, 2015; Marconatto et al., 2019). Similarly, data on gender and non-profit-organizations indicates a relationship between women's empowerment and the non-profit sector, which is viewed as a promoter of gendered leadership (Themudo, 2009). Compared to private for-profit businesses, women are more likely to hold leadership and managerial roles within non-profit organizations and evidence of the greater involvement of women within the governance of these organizations has 
INTERNATIONAL JOURNAL OF ACADEMIC RESEARCH IN BUSINESS AND SOCIAL SCIENCES Vol. 10, No. 3, March, 2020, E-ISSN: 2222-6990 @ 2020 HRMARS

been provided (Teasdale et al. 2011; Claus et al., 2013). Furthermore, some scholars contend that women are better represented in leadership positions in SEs, which have shown more equality in their boards compared to commercial entrepreneurship (Nicolás \& Rubio, 2016; Nair, 2020).

However, unlike the commercial entrepreneurship sector, SE governance issues, such as the gender composition of boards, have thus far been inadequately addressed. Indeed, as highlighted by scholars who have studied corporate governance in the SE sector, while the literature on the governance of voluntary and non-profit organizations is growing, research on SE governance is only recent (Spear et al., 2009; Mswaka \& Aluko, 2015). These scholars have pointed out how board members, as well as managers, play a fundamental role in the success of SEs. This is because they make key decisions that influence the strategic and operational performance of such organizations, thus determining their outcomes and accountability (Spear et al., 2009; Mswaka \& Aluko, 2015). In fact, in making corporate decisions, those responsible for SE governance must balance business and commercial decisions with the social mission of the SE, and therefore balance divergent stakeholder interests (Pestoff \& Hulgård, 2016). This happens regardless of the different governance structures that can be implemented in the SE sector and that depend on the plurality of different legal forms that a SE can take (Spear et al., 2009).

It has been argued that women are likely to pursue social entrepreneurship and become social entrepreneurs because, based on the assumption that women "are prone to care", they are more likely to become involved in community social issues (Hechavarria et al., 2012; Humbert \& Roomi, 2018 , p. 312). Indeed, given their particular mission to create and sustain social value, SEs are able to contribute to the development and change of society, by serving community needs or addressing social and environmental problems (Mair \& Martí, 2006; Kerlin, 2012; Dees, 2018). The way an SE organization is governed plays a decisive role in ensuring the pursuit of this social mission which, via its entrepreneurial processes, brings about societal value outcomes (Del Gesso, 2020, p. 30).

SEs are arousing growing interest as an area of entrepreneurial venture that is creating social innovation (Phillips et al., 2015; Biggeri et al., 2017). Their role has emerged as relevant to the mitigation or resolution of global societal concerns such as poverty, unemployment, illiteracy, health inequities, emigration, women's empowerment, homelessness, social exclusion, environmental degradation, and other social issues that threaten sustainable development and well-being globally (Rahdari et al., 2016; Păunescu \& Evans, 2018; Suchowerska et al., 2019). In particular, the idea that SEs can successfully address social issues related to gender equality and women's empowerment has recently been endorsed in the literature (Fotheringham \& Saunders, 2014; Muntean \& Ozkazanc-Pan, 2016; Doherty, 2018). As a result, it appears that gender issues are gaining widespread interest within the SE sector, thus the intersection between the two fields is increasing (Argyrou \& Charitakis, 2017; McKague \& Harrison, 2019).

Following the above reasoning, SEs can potentially play a crucial role in countering the issue of gender imbalance in leadership roles (Lyon \& Humbert, 2012; Nicolás \& Rubio, 2016). Consequently, they may be more likely to have a balanced representation of women at their top. On this basis, the following hypotheses were formulated:

Hp1: SEs are likely to have gender-balanced corporate leadership.

Hp2: Women's involvement in SE decision-making roles is likely to be encouraged.

The results of previously available studies concerning the same issues have revealed a gender imbalance in favor of males. In particular, Teasdale et al. (2011) found that women were under- 
INTERNATIONAL JOURNAL OF ACADEMIC RESEARCH IN BUSINESS AND SOCIAL SCIENCES

Vol. 10, No. 3, March, 2020, E-ISSN: 2222-6990 @ 2020 HRMARS

represented as leaders of private sector SEs in the UK. Likewise, more recently Lyon \& Humbert (2012) showed that the proportion of women represented on the boards of the UK's SEs was less than that of men. This was especially evident in large SEs operating at national rather than local level. Despite these studies, however, little evidence has been produced about this apparent imbalance. Therefore, further scrutiny is required through the broadening of analysis to the global scale. Indeed, as already noted above, women's representation in SE governance has been under-studied so far, since the available research that has explored the position of women as leaders within SEs is limited to the national context of the UK. Thus, the research reported here may help fill this gap by exploring a sample of the most internationally respected SEs in terms of their social and environmental impacts. Consequently, the originality of this study lies in its focus on the extent of women's representation in governance and managerial roles in the SE arena worldwide in an effort to provide a global picture of this issue.

\section{Sample, Data and Methodology}

\section{Study Sample}

To select the sample to be investigated, this study referred to world leading SEs recognized and awarded over the past five years by the "Schwab Foundation for Social Entrepreneurship". The latter is an internationally operating foundation created in 1998. Its aim is to advance social innovation worldwide, by providing platforms to promote social entrepreneurship for social change and support outstanding social entrepreneurs in their efforts to create a better, more sustainable world (World Economic Forum, 2013). The decision to refer to the data from this foundation was made as it appeared to be particularly suitable for the creation of the study sample; indeed, the annual awardees are selected according to their ability to create impacting solutions for social and environmental challenges and to alleviate problems (Credit Suisse \& Schwab Foundation for Social Entrepreneurship, 2012). Therefore, all the organizations (a total of 77 SEs) steered by the social entrepreneurs awarded since 2015 were considered. They were identified following a search on the Schwab Foundation website (www.schwabfound.org). Subsequently, the websites of each of the 77 SEs were visited between January and February 2020 in order to collect information regarding the gender composition of their corporate governance. Organizations whose websites did not have a specific section describing their composition, such as "governance", "team", "staff", "people", or similar, were excluded. In other words, only organizations for which complete relevant governance data were available were included in the final sample, which therefore consisted of 60 SEs.

As summarized in Table 1, the SEs in the sample cover almost all areas of the world, as their headquarters are located in different states on various continents, especially in the Americas, Asia, Africa, and Europe, while only one SE has its headquarters in Australia. For this reason, in the empirical analysis, the two continents Asia and Oceania were considered as a unique area of analysis, due to their geographical proximity. As a result, five world geographical areas were identified: Africa, Asia \& Oceania, Latin America, North America, and Europe.

The SEs sampled also cover many different macro-sectors of activity, which for simplicity were organized and assigned letters in alphabetical order as follows:

- Education (A);

- Health (B);

- Sustainable Agriculture and Food (C); 
INTERNATIONAL JOURNAL OF ACADEMIC RESEARCH IN BUSINESS AND SOCIAL SCIENCES

Vol. 10, No. 3, March, 2020, E-ISSN: 2222-6990 @ 2020 HRMARS

- Environmental Conservation (D);

- Information and Communication Technology - ICT (E);

- Human Rights and Humanitarian Actions (F);

- Inclusive Growth (G).

Indeed, by operating both at local and international levels, the SEs selected address different social and environmental issues, such as poverty reduction; access to education, healthcare and employment; the empowerment of marginalized communities and vulnerable people; farmer support and rural development; and the protection of the earth's ecosystems, among others.

Table 1: The SEs sampled: number of SEs by Headquarters continent and Macro-sector of activity

\begin{tabular}{lcccccccc}
\hline \multirow{2}{*}{$\begin{array}{l}\text { Headquarters } \\
\text { continent }\end{array}$} & A & B & C & D & E & F & G & Total \\
\hline Africa & 1 & 0 & 2 & 0 & 1 & 2 & 3 & $\mathbf{9}$ \\
\hline Asia \& Oceania & 5 & 3 & 2 & 1 & 1 & 0 & 3 & $\mathbf{1 5}$ \\
\hline Latin America & 1 & 0 & 1 & 1 & 2 & 0 & 3 & $\mathbf{8}$ \\
\hline Europe & 0 & 0 & 1 & 1 & 5 & 1 & 1 & $\mathbf{9}$ \\
\hline North America & 4 & 4 & 2 & 3 & 0 & 4 & 2 & $\mathbf{1 9}$ \\
\hline Total & $\mathbf{1 1}$ & $\mathbf{7}$ & $\mathbf{8}$ & $\mathbf{6}$ & $\mathbf{9}$ & $\mathbf{7}$ & $\mathbf{1 2}$ & $\mathbf{6 0}$ \\
\hline
\end{tabular}

Source: Own elaboration from the collected data.

Data Collection and Methods

The data used in this research was hand-collected directly from the institutional websites of the 60 SEs sampled. The use of websites as a tool to gather reliable online data to be organized in a suitable database for statistical analysis is considered an efficient, quick and convenient alternative to traditional data collection methods, and it is becoming common in academic research (Granello \& Wheaton, 2004).

The composition of the governance of each of the SEs selected was accurately observed in order to collect information about the gender profile of leadership roles. In particular, the gender composition of the SE boards, such as the board of directors or the executive board, was scrutinized by counting the number of women out of the total of board members. In contrast, when such boards were not available due to the different governance structures of the SEs sampled, the leadership positions of the SE team or staff were considered. Thus, for those SEs that did not present an explicit configuration of their boards or even information about the leadership team on their website, the leadership positions were filtered from the general staff (i.e. the CEO or the chairperson, directors, chief officers, and managers); then, how many of these positions were held by women were counted.

In order to validate the two hypotheses formulated in the Literature Review, the empirical data, once collected, were processed through the calculation of different statistical methods, both univariate and bivariate. In particular, two different measures of associations (Berry et al., 2018) were computed on the contingency tables, which report, respectively, the number of women and the total number of members in leadership positions, by headquarters continent and macro-sector of activity (see Tables 2-3 in the next section). The first is the classic Pearson's $\chi^{2}$ measure of (symmetric) association between two factors: 
INTERNATIONAL JOURNAL OF ACADEMIC RESEARCH IN BUSINESS AND SOCIAL SCIENCES Vol. 10, No. 3, March, 2020, E-ISSN: 2222-6990 @ 2020 HRMARS

$$
\chi^{2}=\sum_{i=1}^{r} \sum_{j=1}^{c} \frac{\left(n_{i j}-\bar{n}_{i j}\right)^{2}}{\bar{n}_{i j}}
$$

where $n_{i j}$ and $\bar{n}_{i j}$ are the observed frequencies in the contingency table and the theoretical independence frequencies, respectively. The usual test with the null hypothesis $H_{0}: n_{i j}=\bar{n}_{i j}, \forall(i, j)$ was performed, in order to assess if the two variables could be considered significantly associated. The second association index is Goodman-Kruskal's $\tau_{Y \mid X}$, which is an asymmetric measure considering variable $Y$ (i.e. the macro-sectors) as dependent, and variable $X$ (i.e. the continent where the headquarters is located) as independent; $\tau_{Y \mid X}$ measures the proportional reduction of heterogeneity in the conditional distributions of $Y$ given $X$, and ranges from 0 (no reduction) to 1 (complete reduction, i.e. perfect homogeneity in the conditional distributions). The computational form given for this index is:

$$
\tau_{Y \mid X}=\frac{N \sum_{i=1}^{r} \sum_{j=1}^{c} \frac{n_{i j}^{2}}{n_{0 j}}-\sum_{i=1}^{r} n_{i 0}^{2}}{N^{2}-\sum_{i=1}^{r} n_{i 0}^{2}}
$$

where $N$ is the total number of observations in the contingency table, and $n_{i 0}$ and $n_{0 j}$ are the marginal frequencies relating to the $x_{i}{ }^{\prime}$ s and $y_{j}{ }^{\prime}$ s, respectively. Furthermore, another descriptive statistical method was applied, i.e. (simple) correspondence analysis (Murtagh, 2005); the main output of the method is a simple and intuitive graphical representation of the associations between the considered characteristics in the two collectives.

Finally, two classical statistical hypothesis tests were carried out. These were employed to evaluate the statistical significance of a hypothetical balanced presence of women at the top of SEs, thus allowing inferences to be made about the extent of women's representation in decision-making roles in the SE environment, based on the tests' p-values. Indeed, a p-value expresses "the observed significance level for the test hypothesis" (Greenland et al., 2016, p. 339). All data analyses were performed using the open source software R, version 3.6.2.

\section{Data Analysis and Results}

This section presents the results of the data analysis which combined descriptive statistics (univariate and bivariate) and inferential statistics. These results led to the two hypotheses underlying this study being validated or rejected.

Table 2 gives a first glance of the total number of women holding leadership positions (an absolute value of 330 women) in the SEs sampled. It also gives an indication of the extent to which this number varies over the different geographical areas of the world and in the main macro-sectors of activity. A first reading of this data indicates that, in terms of absolute values, the highest representation of women leaders is found in those SEs that have their headquarters in North America and in those that operate in the macro-sector of education (A). This result was somewhat expected, considering that the largest number of SEs in the sample is located in North America and that education is among the activity sectors most represented in terms of the number of SEs (see also Table 1 for more details). More precisely, Table 2 presents the contingency table obtained by jointly considering the headquarters continent and the macro-sector of activity of the SEs with respect to the presence of women in leadership positions. The first result is the Pearson's $\chi^{2}$, which gave a value of 346.04; this means, for an $\chi^{2}$ random variable with $(r-1)(c-1)=(5-1)(7-1)=24$ 
INTERNATIONAL JOURNAL OF ACADEMIC RESEARCH IN BUSINESS AND SOCIAL SCIENCES Vol. 10, No. 3, March, 2020, E-ISSN: 2222-6990 @ 2020 HRMARS

degrees of freedom, a p-value $p<0.001$, which suggests that there is some sort of association between the two variables. On the other hand, the low value of Goodman-Kruskal's index, $\tau_{Y \mid X}=0.211$ shows a weak association of the seven macro-sectors of activity with the five geographical areas where SEs have their headquarters (remember that $\tau_{Y \mid X}$ is an asymmetric measure of association, while $\chi^{2}$ is symmetric). This is better evident in Figure 1, where this association is graphically represented as the result of correspondence analysis. As is clearly visible in this figure, only a high association stands out between the ICT macro-sector (E) and Europe; there are also some associations between the education macro-sector $(A)$ and Asia \& Oceania, between the inclusive growth macro-sector $(\mathrm{G})$ and Latin America, and between the latter macro-sector and Africa. This leads to the affirmation that, in these geographical areas, the number of women leaders within the SE environment could be concentrated in some macro-sectors of activity at the expenses of the others. Indeed, women leaders appear more likely to be found in Europe in the ICT macro-sector; in Asia \& Oceania in the education macro-sector; and in Latin America and Africa in the inclusive growth macro-sector. For North America, the data show a more homogeneous spread of women leaders in the various SE macro-sectors of activity. Therefore, women appear to be quite heterogeneously represented in SE leadership roles in the various sectors of intervention, both within and among the different areas of the globe; a better and wider representation occurs in the North American context (Table 2 and Figure 1). However, the $\tau_{Y \mid X}=0.211$ shows that this heterogeneity of women's representation in leadership positions is reduced by $21 \%$ on average within individual geographical areas, i.e. the conditional probability distributions of various macro-sectors within each continent are slightly less heterogeneous (hence, slightly more homogeneous).

Table 2: Contingency Table between the Headquarters continent and the Macro-sector of activity Women's Counts

Macro-sector of activity

\begin{tabular}{lcccccccc}
\cline { 2 - 8 } $\begin{array}{l}\text { Headquarters } \\
\text { continent }\end{array}$ & A & B & C & D & E & F & G & Total \\
\hline Africa & 1 & 0 & 4 & 0 & 3 & 10 & 14 & $\mathbf{3 2}$ \\
\hline Asia \& Oceania & 42 & 5 & 4 & 3 & 6 & 0 & 6 & $\mathbf{6 6}$ \\
\hline Latin America & 7 & 0 & 9 & 2 & 6 & 0 & 31 & $\mathbf{5 5}$ \\
\hline Europe & 0 & 0 & 4 & 0 & 37 & 2 & 4 & $\mathbf{4 7}$ \\
\hline North America & 34 & 31 & 19 & 16 & 0 & 18 & 12 & $\mathbf{1 3 0}$ \\
\hline Total & $\mathbf{8 4}$ & $\mathbf{3 6}$ & $\mathbf{4 0}$ & $\mathbf{2 1}$ & $\mathbf{5 2}$ & $\mathbf{3 0}$ & $\mathbf{6 7}$ & $\mathbf{3 3 0}$ \\
\hline
\end{tabular}

Source: Own construction from the data analysis on gendered leadership of selected SEs. 


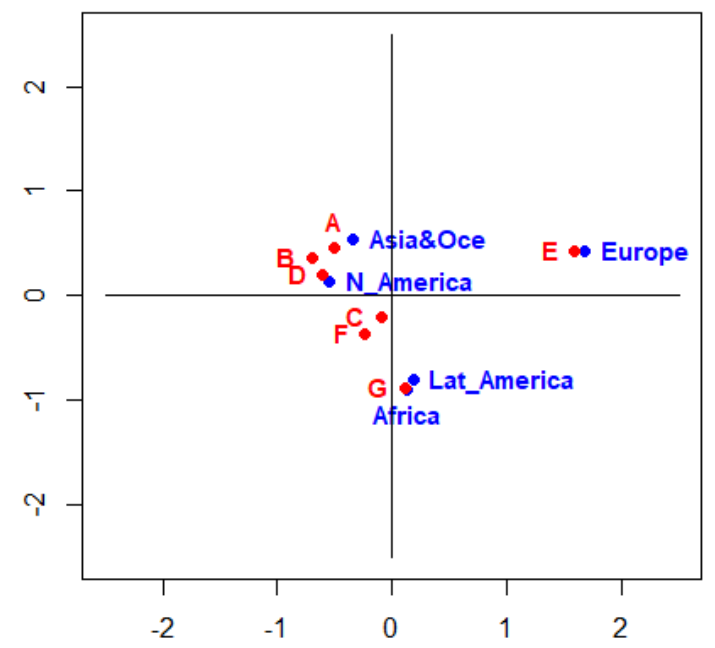

Figure 1: Correspondence Analysis graphical results for data in Table 2

Source: Own elaboration.

Regarding the total counts, i.e. the overall leadership positions of the selected SEs (Table 3), the results are similar to those referring to the women's counts: $\chi^{2}=592.07$, again with 24 degrees of freedom, giving $p<0.001$ and indicating association between the variables taken into account. In addition, the low $\tau_{Y \mid X}$ value confirms the weak association of the seven macro-sectors of activity with the five geographical areas where SEs have their headquarters. Indeed, its value of 0.154 indicates that the heterogeneity of leadership positions among macro-sectors of activity is slightly reduced (by $15 \%$ on average) within individual geographic areas; hence, a slightly higher propensity for homogeneity for the distribution of the macro-sectors within each continent is confirmed. The results shown above are further corroborated when read in combination with the graphical correspondence analysis results depicted in Figure 2.

Table 3: Contingency Table between the Headquarters continent and the Macro-sector of activity Total Counts

\begin{tabular}{lcccccccc}
\hline & \multicolumn{8}{c}{ Macro-sector of activity } \\
\cline { 2 - 10 } $\begin{array}{l}\text { Headquarters } \\
\text { Continent }\end{array}$ & A & B & C & D & E & F & G & Total \\
\hline Africa & 7 & 0 & 18 & 0 & 13 & 18 & 34 & $\mathbf{9 0}$ \\
\hline Asia \& Oceania & 71 & 18 & 11 & 6 & 8 & 0 & 24 & $\mathbf{1 3 8}$ \\
\hline Latin America & 12 & 0 & 26 & 5 & 11 & 0 & 52 & $\mathbf{1 0 6}$ \\
\hline Europe & 0 & 0 & 10 & 3 & 85 & 10 & 30 & $\mathbf{1 3 8}$ \\
\hline North America & 55 & 64 & 31 & 38 & 0 & 42 & 18 & $\mathbf{2 4 8}$ \\
\hline Total & $\mathbf{1 4 5}$ & $\mathbf{8 2}$ & $\mathbf{9 6}$ & $\mathbf{5 2}$ & $\mathbf{1 1 7}$ & $\mathbf{7 0}$ & $\mathbf{1 5 8}$ & $\mathbf{7 2 0}$ \\
\hline
\end{tabular}

Source: Own construction from the data analysis on gendered leadership of selected SEs. 
INTERNATIONAL JOURNAL OF ACADEMIC RESEARCH IN BUSINESS AND SOCIAL SCIENCES Vol. 10, No. 3, March, 2020, E-ISSN: 2222-6990 @ 2020 HRMARS

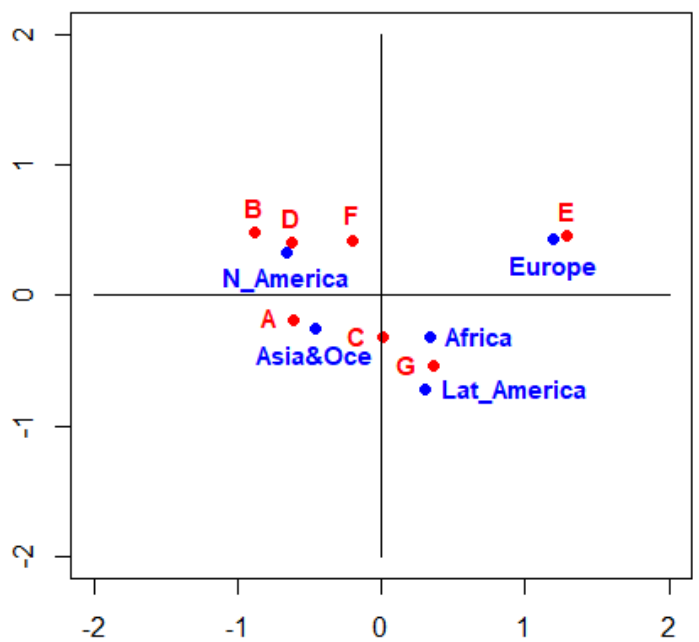

Figure 2: Correspondence Analysis graphical results for data in Table 3 Source: Own elaboration.

Better evidence of women's representation at the top of the SEs is given by the data shown in Table 4 , which reports the proportion of women in leadership roles, again by macro-sector of activity and by the geographical area in which the SEs are headquartered. As can be seen from this table, on average, women hold $45.83 \%$ of leadership positions, with a slight imbalance in favor of men. North America is confirmed to be the area of the world in which SEs are located with the greatest involvement of women in their leadership positions (with an average per macro-sector of activity of $52.42 \%$ ), highlighting three female-dominated sectors (education, sustainable agriculture \& food, and inclusive growth). SEs in Latin America also show a high representation of women in leadership roles (with an average per macro-sector of activity of $51.89 \%$ ); this area highlights three femaledominated sectors (education, ICT, and inclusive growth), although women are still underrepresented in the sustainable agriculture \& food macro-sector. Furthermore, SEs are also close to gender balance at their top in Asia \& Oceania (with an average per macro-sector of activity of 47.83\%); in this area, however, three female-dominated sectors (education, environmental conservation, and ICT) counterbalance three male-dominated sectors (health, sustainable agriculture $\&$ food, and inclusive growth). Conversely, a substantial gender imbalance remains in SEs which have their headquarters both in Africa (35.56\% of women in leadership positions) and Europe (34.06\%). In Africa, women predominate as leaders in SEs operating in the macro-sector of human rights \& humanitarian actions but are under-represented in those operating in other macro-sectors of activity. Finally, the worst involvement of women in SE leadership positions occurs in Europe where women are mostly under-represented in the various macro-sectors of activity.

Shifting the focus to the macro-sectors of activity, education is confirmed to be the SE field with the greatest representation of women in leadership roles (with an average per continent of $57.93 \%)$. Another positive note is that, in each macro-sector as a whole, the average percentage of women who hold leadership roles never drops below $40.38 \%$. 
INTERNATIONAL JOURNAL OF ACADEMIC RESEARCH IN BUSINESS AND SOCIAL SCIENCES Vol. 10, No. 3, March, 2020, E-ISSN: 2222-6990 @ 2020 HRMARS

Table 4: Percentage of women in leadership roles out of total of leadership roles, by Headquarters continent and by Macro-sector of activity

\begin{tabular}{lcccccccc}
\hline & \multicolumn{8}{c}{ Macro-sector of activity } \\
\cline { 2 - 9 } $\begin{array}{l}\text { Headquarters } \\
\text { continent }\end{array}$ & A & B & C & D & E & F & G & Total \\
\hline Africa & 14.29 & - & 22.22 & - & 23.08 & 55.56 & 41.18 & $\mathbf{3 5 . 5 6}$ \\
\hline Asia \& Oceania & 59.15 & 27.78 & 36.36 & 50.00 & 75.00 & - & 25.00 & $\mathbf{4 7 . 8 3}$ \\
\hline Latin America & 58.33 & - & 34.62 & 40.00 & 54.55 & - & 59.62 & $\mathbf{5 1 . 8 9}$ \\
\hline Europe & - & - & 40.00 & - & 43.53 & 20.00 & 13.33 & $\mathbf{3 4 . 0 6}$ \\
\hline North America & 61.82 & 48.44 & 61.29 & $\mathbf{4 2 . 1 1}$ & - & 42.86 & 66.67 & $\mathbf{5 2 . 4 2}$ \\
\hline Total & $\mathbf{5 7 . 9 3}$ & $\mathbf{4 3 . 9 0}$ & $\mathbf{4 1 . 6 7}$ & $\mathbf{4 0 . 3 8}$ & $\mathbf{4 4 . 4 4}$ & $\mathbf{4 2 . 8 6}$ & $\mathbf{4 2 . 4 1}$ & $\mathbf{4 5 . 8 3}$ \\
\hline
\end{tabular}

Source: Own construction from the data analysis on gendered leadership of selected SEs.

Figure 3 shows the percentage distribution of women in leadership positions in the 60 selected SEs: the number of male-dominated SEs (colored in light green) is prevalent over the number of gender balanced SEs (colored in mid green) and the number of female-dominated SEs (colored in dark green). Indeed, male-dominated SEs with a percentage of women in leadership positions between $0 \%$ and $40 \%$ total 30 organizations, representing $50 \%$ of the sample. It is noted that there are only 2 SEs with more than $80 \%$ of women in leadership positions to counterbalance 11 SEs that have less than $20 \%$ of women in these positions; in addition, while there are 3 SEs with less than $10 \%$ of women leaders, there are no SEs with over $90 \%$.

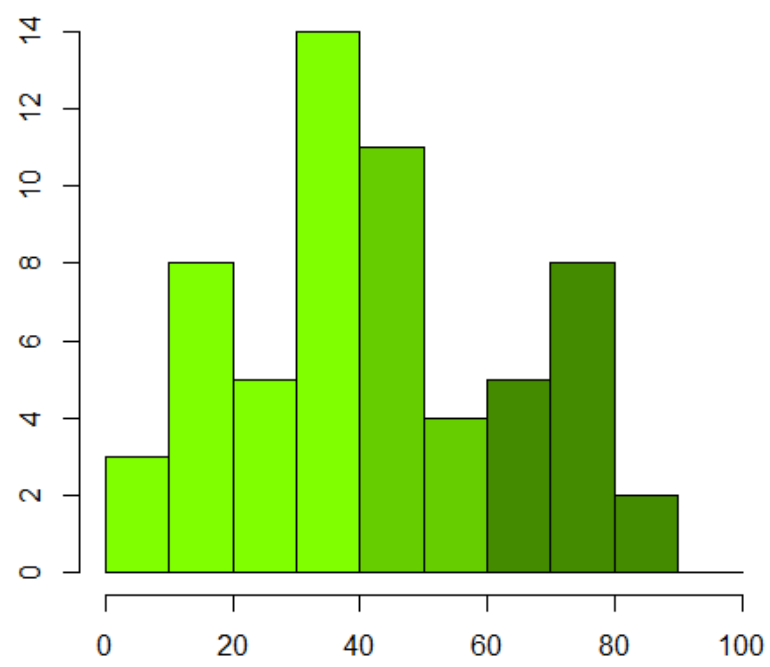

Figure 3: Percentage distribution of women in leadership roles in the selected SEs Source: Own construction.

Table 5 below shows the results of the two statistical hypothesis tests, allowing inferences to be made about the extent of women's representation in decision-making roles in the SE environment. The first hypothesis test put the presence of women in leadership positions at 50\%, assuming therefore an egalitarian proportion of women and men (or gender-balanced leadership). The alternative hypothesis was that women in leadership positions are less than half of the total. The hypothesis test 
INTERNATIONAL JOURNAL OF ACADEMIC RESEARCH IN BUSINESS AND SOCIAL SCIENCES Vol. 10, No. 3, March, 2020, E-ISSN: 2222-6990 @ 2020 HRMARS

covered all the SEs in the sample based on the average percentage of women who hold leadership positions (sample estimate $=0.458$ ). The $p$-value $p<0.013$, which expresses the statistical significance for the alternative hypothesis tested, leads to the conclusion that women in leadership positions are still significantly less than 50\%; therefore, the hypothesis of a gender-balanced leadership in the SE environment is rejected.

The second hypothesis test concerned the presence of women in leadership positions within SEs with a female CEO and covered, therefore, solely those SEs that have a female CEO or chairperson. Notably, the CEO/chairperson is a woman in almost half of the SEs sampled (in 27 organizations out of 60). As can be seen from Table 5, 161 women hold leadership positions out of a total of 301 positions in the SEs with a female CEO or chairperson (giving a sample estimate of 0.535). The alternative hypothesis was therefore that women in leadership positions in these SEs are likely to outnumber men in the same positions. However, the $p$-value of 0.112 indicates that the proportion of women leaders in SEs with female CEOs is not significantly different from the proportion of male leaders. Consequently, it is not possible to conclude that there are more women than men in leadership positions within SEs with a female CEO (no same gender co-optation effect).

Table 5: Statistical hypothesis tests regarding the proportion of women in leadership positions

\begin{tabular}{lllccc}
\hline & $\begin{array}{c}\text { Total } \\
\text { leadership } \\
\text { positions }\end{array}$ & $\begin{array}{c}\text { Women in } \\
\text { leadership } \\
\text { positions }\end{array}$ & $\begin{array}{c}\text { Prop. women in } \\
\text { leadership } \\
\text { positions }\end{array}$ & $\begin{array}{c}\text { Tested } \\
\text { alternative Hp. }\end{array}$ & $\boldsymbol{p}$ \\
\hline All SEs sampled & $n_{L}=720$ & $n_{L W}=330$ & $p_{L W}=.458$ & $\pi_{L W}<.5$ & 0.013 \\
\hline $\begin{array}{l}\text { SEs with a } \\
\text { female CEO or }\end{array}$ & $\begin{array}{l}n_{L(W C E O)} \\
\text { chairperson }\end{array}$ & $\begin{array}{l}n_{L W(W C E O)} \\
=301\end{array}$ & $\begin{array}{l}p_{L W(W C E O)} \\
=.535\end{array}$ & $\pi_{L W(W C E O)}>.5$ & 0.112 \\
\hline
\end{tabular}

Source: Own elaborations from the data analysis on gendered leadership of selected SEs.

Based on the results of the above statistical analyses, decisions can now be drawn with respect to the two hypotheses underlying this study. In particular, it is possible to conclude that:

$H p 1$ (SEs are likely to have gender-balanced corporate leadership) is not validated neither in descriptive nor in inferential terms and consequently, this hypothesis is rejected;

Hp2 (Women's involvement in SE decision-making roles is likely to be encouraged) can be validated in descriptive terms but not in inferential terms.

\section{Discussion and Conclusion}

This study sought to provide an overall picture of women's representation in corporate governance and managerial roles in the SE environment by exploring the gender composition of boards or leadership positions in a sample of 60 world leading SEs. The study was underpinned by two research hypotheses, which assumed that SEs would be likely to provide evidence of gender-balanced corporate leadership ( $\mathrm{Hp} 1$ ) and would encourage women's involvement in decision-making roles (Hp2). In order to validate these hypotheses, an empirical analysis was therefore performed on the sample of SE data by combining descriptive statistics and inferential statistics. The results of the statistical analyses, as presented in the previous section, did not allow $\mathrm{Hp} 1$ to be validated, whereas they did allow for the validation of $\mathrm{Hp} 2$ although merely in descriptive terms. 
INTERNATIONAL JOURNAL OF ACADEMIC RESEARCH IN BUSINESS AND SOCIAL SCIENCES Vol. 10, No. 3, March, 2020, E-ISSN: 2222-6990 @ 2020 HRMARS

In particular, this study found that women's representation in managerial and governance roles within the SE environment is still unbalanced in favor of men, both in descriptive and inferential terms. Indeed, in inferential terms, the proportion of women serving in leadership positions was found to be significantly less than $50 \%$, which means that men holding these positions are still in greater numbers than women. In addition, in descriptive terms, the results revealed that the average percentage $(45.83 \%)$ of women at the top of the SEs sampled showed a slight imbalance in favor of men; however, male-dominated SEs (with women in leadership positions between $0 \%$ and $40 \%$ ) made up half of the sample of SEs. All the aforesaid results allow the study to conclude that, on a global scale, SEs have not yet statistically reached gender-balanced corporate leadership. This is consistent with the results of previous studies which have shown an under-representation of women in the governance sphere of SEs in the UK, thus highlighting a gender-imbalanced leadership in this area (Teasdale et al., 2011; Lyon \& Humbert, 2012). Ultimately, the paths followed by women's representation in leadership positions within the SE environment at a global level appear to be analogous to those followed within SEs at the national level in the UK context.

However, this study revealed that the extent to which the proportion of women who hold leadership roles is spread over the different geographical areas of the world is quite variable among the various continents. Indeed, North America was found to be the geographical area in which SEs are headquartered with the greatest involvement of women in their governance, followed by Latin America (52.42\% and 51.89\%, respectively). In addition, SEs are close to gender-balanced leadership in Asia \& Oceania (47.83\% of women in leadership positions); whereas, a substantial gender imbalance remains in SEs that have their headquarters in Africa and in those in Europe, which surprisingly showed the lowest representation of women in leadership roles (35.56\% and 34.06\%, respectively). A likely explanation for this can possibly be found in the cultural differences linked to gender minded and female empowerment which persist among the various countries. These cultural differences, as well as the varying degrees of development in these countries, might be sources of gaps in women's involvement in corporate boardrooms or at the top levels of corporate management. However, as advocated by the literature, SEs can potentially play a crucial role in reducing and contrasting all sorts of gender-related economic, cultural and social differences and gaps (Fotheringham \& Saunders, 2014; Muntean \& Ozkazanc-Pan, 2016; Doherty, 2018).

Furthermore, women's representation in leadership roles is also spread differently among the various macro-sectors of activity in which the SEs operate. Indeed, a high proportion of women's representation in the management and governance systems of SEs operating in the field of education was highlighted. Notably, education was found to be a female-dominated SE sector of activity in most geographical areas of the world, with the exception of Africa, where women who had ascended to executive and director positions predominated in the human rights \& humanitarian actions macrosector. A possible explanation for the different involvement of women in the different sectors of activity, which might also be physiological due to the specificity of the activities, can be found in the different levels of development of countries. Precisely in this regard, Nicolás \& Rubio (2016) have shown that a country's level of development influences women's participation in SEs. Future research could further the present study by exploring women's representation in the management and governance systems of SEs in different areas of the world and in the various sectors of activity in which they operate. 
INTERNATIONAL JOURNAL OF ACADEMIC RESEARCH IN BUSINESS AND SOCIAL SCIENCES Vol. 10, No. 3, March, 2020, E-ISSN: 2222-6990 @ 2020 HRMARS

The notion that SEs may encourage women's involvement in decision-making roles was adopted as a second hypothesis in this study. Based on the results of the statistical analyses, it can be said that this proved to be plausible in the SEs observed. Indeed, while on the one hand the results of the descriptive statistics indicate that these SEs have not yet achieved a fully gender-balanced corporate leadership, on the other hand they show that the gender gap is not substantial since women hold on average $45.83 \%$ of leadership positions. In addition, several female-dominated SEs operate in different fields of activity in North America, Latin America and Asia \& Oceania (see Table 4 for more details) and the average percentage of women in leadership roles never drops below $40.38 \%$ in each SE macro-sector of activity as a whole. Furthermore, almost half of the SEs sampled have a female CEO or chairperson and, within these SEs, the total number of women in leadership positions is greater than men (161 vs 140). However, the hypothesis test results did not confirm the potential for SEs to encourage the representation of women in leadership roles in inferential terms. In spite of this, the above results suggest that overall, women's participation in decision-making roles in the SEs observed is encouraged. This is in line with the literature that highlights the great ability of SEs to reduce gender gaps and promote women's involvement in the corporate decision-making environment (Nicolás \& Rubio, 2016; Nair, 2019).

Following the above discussion, it is possible to conclude that, despite SEs not having yet proven to have reached a gender-balanced corporate leadership on a global scale, they provide evidence of an ability to promote women's involvement in decision-making. This conclusion may be noteworthy in terms of its contribution to the advancement of existing knowledge, which has been achieved by focusing the study's lens on the extent of women's representation in governance and managerial roles in the SE arena worldwide.

In summary, the findings of this study, while confirming the powerful potential for SEs to promote women's representation in decision-making processes, indicate how efforts are still needed so that this potential can be substantiated in achieving gender-balanced management and governance systems. Indeed, this research found that women are still under-represented in corporate governance and managerial positions within the SE sector across the world, but at the same time highlighted how SEs are still one step away from achieving gender balance on a global scale. Further efforts are therefore recommended as part of the overall endeavors of SEs to create a more sustainable world. As a result, an additional effort in terms of greater involvement of women in leadership and corporate boards would allow these organizations to achieve gender balance in the not too distant future. Advancing gender parity and women's empowerment as well as reducing all forms of social exclusion are part of those pathways to sustainable societal development and cultural change in which SEs have proven to be at the forefront.

Finally, this research could have both theoretical and practical implications as it draws the attention of scholars and practitioners to the issue of women's involvement in corporate boardrooms and at the top levels of corporate management. This matter remains unresolved on a social, economic and cultural level. An outline of the general picture of the SE environment can both inspire future inquiries and assist social entrepreneurs by promoting a greater awareness of their potential for social innovation. 
INTERNATIONAL JOURNAL OF ACADEMIC RESEARCH IN BUSINESS AND SOCIAL SCIENCES

Vol. 10, No. 3, March, 2020, E-ISSN: 2222-6990 @ 2020 HRMARS

\section{References}

Argyrou, A., \& Charitakis, S. (2017). Gender equality in employment utilizing female social entrepreneurship in Greece. International and Comparative Corporate Law Journal, 12(2), 3660.

Berry, K. J., Johnston, J. E., Mielke, P. W. Jr. (2018). The measurement of association. A permutation statistical approach. Cham, Switzerland: Springer. https://doi.org/10.1007/978-3-319-98926-6

Biggeri, M., Testi, E., \& Bellucci, M. (2017). Enabling ecosystems for social enterprises and social innovation: A capability approach perspective.Journal of Human Development and Capabilities, 18(2), 299-306. https://doi.org/10.1080/19452829.2017.1306690

Claus, V. A., Callahan, J., \& Sandlin, J. R. (2013). Culture and leadership: Women in nonprofit and forprofit leadership positions within the European Union. Human Resource Development International, 16(3), 330-345. https://doi.org/10.1080/13678868.2013.792489

Credit Suisse \& Schwab Foundation for Social Entrepreneurship (2012). Investing for impact: How social entrepreneurship is redefining the meaning of return. Zurich, Switzerland: Credit Suisse Research Institute. Available at: https://www.issuelab.org/resource/investing-for-impact-howsocial-entrepreneurship-is-redefining-the-meaning-of-return.html

Dees, J. G. (2018). The meaning of social entrepreneurship. In J. Hamschmidt \& M. Pirson (Eds.), Case studies in social entrepreneurship and sustainability: The oikos collection (pp. 34-42). New York, USA: Routledge. http://dx.doi.org/10.4324/9781351278560-5

Del Gesso, C. (2020). An entrepreneurial identity for social enterprise across the institutional approaches: From mission to accountability toward sustainable societal development. International Journal of Business and Management, 15(1), pp. 16-35. https://doi.org/10.5539/ijbm.v15n1p16

Doherty, B. (2018), Gender equality and women's empowerment through fair trade social enterprise: Case of Divine Chocolate and Kuapa Kokoo. In N. Apostolopoulos, H. Al-Dajani, D. Holt, P. Jones \& R. Newbery (Eds.), Entrepreneurship and the Sustainable Development Goals (pp. 151163). Bingley, UK: Emerald Publishing Limited. https://doi.org/10.1108/S2040724620180000008014

Fotheringham, S., \& Saunders, C. (2014). Social enterprise as poverty reducing strategy for women. Social Enterprise Journal, 10(3), 176-199. https://doi.org/10.1108/SEJ-06-2013-0028

Glass, C., \& Cook, A. (2016). Leading at the top: Understanding women's challenges above the glass ceiling. The Leadership Quarterly, 27(1), 51-63. https://doi.org/10.1016/j.leaqua.2015.09.003

Granello, D. H., \& Wheaton, J. E. (2004). Online data collection: Strategies for research. Journal of Counseling \& Development, 82(4), 387-393. https://doi.org/10.1002/j.15566678.2004.tb00325.x

Greenland, S., Senn, S. J., Rothman, K. J., Carlin, J. B., Poole, C., Goodman, S. N., \& Altman, D. G. (2016). Statistical tests, P values, confidence intervals, and power: A guide to misinterpretations. European Journal of Epidemiology, 31(4), 337-350. https://doi.org/10.1007/s10654-016-0149-3

Hechavarria, D. M., Ingram, A., Justo, R., \& Terjesen, S. (2012). Are women more likely to pursue social and environmental entrepreneurship. In K. D. Hughes \& J. E. Jennings (Eds.), Global women's entrepreneurship research: Diverse settings, questions and approaches (pp. 135-151). Cheltenham, UK: Edward Elgar Publishing Limited. 
INTERNATIONAL JOURNAL OF ACADEMIC RESEARCH IN BUSINESS AND SOCIAL SCIENCES

Vol. 10, No. 3, March, 2020, E-ISSN: 2222-6990 @ 2020 HRMARS

Hoyt, C. L. (2010). Women, men, and leadership: Exploring the gender gap at the top. Social and Personality Psychology Compass, 4(7), 484-498. https://doi.org/10.1111/j.17519004.2010.00274.x

Humbert, A. L., \& Roomi, M. A. (2018). Prone to "care"? Relating motivations to economic and social performance among women social entrepreneurs in Europe. Social Enterprise Journal, 14(3), 312-327. https://doi.org/10.1108/SEJ-11-2017-0058

Kerlin, J. A. (2012). Defining social enterprise across different contexts. A conceptual framework based on institutional factors. Nonprofit and Voluntary Sector Quarterly, 42(1), 84-108. https://doi.org/10.1177/0899764011433040

Lyon, F., \& Humbert, A. L. (2012). Gender balance in the governance of social enterprise. Local Economy, 27(8), 831-845. https://doi.org/10.1177/0269094212455158

Mair, J., \&Martí , I. (2006). Social entrepreneurship research: A source of explanation, prediction, and delight. Journal of World Business, 41(1), 36-44. http://dx.doi.org/10.1016/j.jwb.2005.09.002

Marconatto, D., Ladeira, W. J., \& Wegner, D. (2019). The sustainability of solidarity economy organizations: An empirical investigation. Journal of Cleaner Production, 228, 1122-1130. https://doi.org/10.1016/j.jclepro.2019.04.352

McKague, K., \& Harrison, S. (2019). Gender and health social enterprises in Africa: A research agenda. International Journal for Equity in Health, 18(1), 95. https://doi.org/10.1186/s12939019-0994-2

Mswaka, W., \& Aluko, O. (2015). Corporate governance practices and outcomes in social enterprises in the UK: A case study of South Yorkshire. International Journal of Public Sector Management, 28(1), 57-71. https://doi.org/10.1108/IJPSM-03-2014-0048

Muntean, S. C., \& Ozkazanc-Pan, B. (2016). Feminist perspectives on social entrepreneurship: Critique and new directions. International Journal of Gender and Entrepreneurship, 8(3), 221-241. https://doi.org/10.1108/IJGE-10-2014-0034

Murtagh, F. (2005). Correspondence Analysis and Data Coding with Java and R. Florida, USA: Chapman \& Hall/CRC. https://doi.org/10.1201/9781420034943

Nair, S. R. (2019). To examine women social entrepreneurial ecosystems: Opportunities and challenges. In J. M. Palma-Ruiz, Á. Herrero-Crespo \& J. M. Saiz-Álvarez (Eds.), Handbook of research on smart territories and entrepreneurial ecosystems for social innovation and sustainable growth (pp. 326-345). Pennsylvania, USA: IGI Global.

Nicolás, C., \& Rubio, A. (2016). Social enterprise: Gender gap and economic development. European Journal of Management and Business Economics, 25(2), 56-62. https://doi.org/10.1016/j.redeen.2015.11.001

Păunescu, C., \& Evans, R. (2018). The role of social enterprises at European level. In A. M. Dima (Ed.), Doing business in Europe: Economic integration processes, policies, and the business environment, (pp. 235-254). Cham, Switzerland: Springer.

Périlleux, A., \& Szafarz, A. (2015). Women leaders and social performance: evidence from financial cooperatives in Senegal. World Development, 74, 437-452. https://doi.org/10.1016/j.worlddev.2015.05.011

Pestoff, V., \& Hulgård, L. (2016). Participatory governance in social enterprise. Voluntas: International Journal of Voluntary and Nonprofit Organizations, 27(4), 1742-1759.

http://dx.doi.org/10.1007/s11266-015-9662-3 
INTERNATIONAL JOURNAL OF ACADEMIC RESEARCH IN BUSINESS AND SOCIAL SCIENCES

Vol. 10, No. 3, March, 2020, E-ISSN: 2222-6990 @ 2020 HRMARS

Phillips, W., Lee, H., Ghobadian, A., O’Regan, N., \& James, P. (2015). Social innovation and social entrepreneurship: A systematic review. Group \& Organization Management, 40(3), 428-461. https://doi.org/10.1177/1059601114560063

Rahdari, A., Sepasi, S., \& Moradi, M. (2016). Achieving sustainability through Schumpeterian social entrepreneurship: The role of social enterprises. Journal of Cleaner Production, 137, 347-360. https://doi.org/10.1016/j.jclepro.2016.06.159

Spear, R., Cornforth, C., \& Aiken, M. (2009). The governance challenges of social enterprises: Evidence from a UK empirical study. Annals of Public and Cooperative Economics, 80(2), 247-273. https://doi.org/10.1111/j.1467-8292.2009.00386.x

Suchowerska, R., Barraket, J., Qian, J., Mason, C., Farmer, J., Carey, G., Campbell, P., \& Joyce, A. (2019). An organizational approach to understanding how social enterprises address health inequities: A scoping review. Journal of Social Entrepreneurship, 1-25. https://doi.org/10.1080/19420676.2019.1640771

Teasdale, S., McKay, S., Phillimore, J., \& Teasdale, N. (2011). Exploring gender and social entrepreneurship: Women's leadership, employment and participation in the third sector and social enterprises. Voluntary Sector Review, 2(1), 57-76. https://doi.org/10.1332/204080511X560620

Themudo, N. S. (2009). Gender and the nonprofit sector. Nonprofit and Voluntary Sector Quarterly, 38(4), 663-683. https://doi.org/10.1177/0899764009333957

World Economic Forum. (2013). Breaking the binary: Policy guide to scaling social innovation. Geneva, Switzerland: Schwab Foundation for Social Entrepreneurship. Available at: http://www3.weforum.org/docs/WEF_Breaking_Binary_Policy_Guide_Scaling_Social_Innovat ion_2013_2604.pdf 